\title{
Editorial: Palaeoecology of Easter Island: Natural and Anthropogenic Drivers of Ecological Change
}

\author{
Valentí Rull* and Santiago Giralt \\ Institute of Earth Science Jaume Almera, ICTJA, CSIC, Barcelona, Spain
}

Keywords: Easter Island, Rapa Nui, deforestation, cultural change, climate change, ecological collapse, cultural collapse, last millennia

\section{The Editorial on the Research Topic}

\section{Palaeoecology of Easter Island: Natural and Anthropogenic Drivers of Ecological Change}

Easter Island (Rapa Nui), the most remote inhabited place on Earth, lies in an intermediate position between Polynesia and South America, which has led to contrasting hypotheses regarding their human colonization and the ensuing ecological impacts (Heyerdahl, 1989; Flenley and Bahn, 2003; Hunt and Lipo, 2006; Thorsby, 2012). The small size, the isolation and the possibility of past climatic and ecological reconstructions before and after human settlement make the island a natural laboratory to disentangle climatic and anthropogenic causes of past ecological change, which is useful to develop predictive models of ecological responses to future climate changes. The first palaeoecological studies (Flenley and King, 1984; Flenley et al., 1991) suggested the occurrence of an ecological catastrophe-as indicated by an abrupt island-wide deforestationduring the last millennium, followed by a cultural collapse of the ancient Rapanui civilization that built the emblematic megalithic statues called moais. Such socio-ecological demise was considered an ecocide, as a result of over-exploitation of natural resources by the first settlers,

\section{OPEN ACCESS}

Edited and reviewed by: Franco Biondi,

University of Nevada, Reno, United States

*Correspondence: Valentí Rull vrull@ictja.csic.es

Specialty section: This article was submitted to Paleoecology,

a section of the journal

Frontiers in Ecology and Evolution

Received: 29 May 2018

Accepted: 29 June 2018

Published: 19 July 2018

Citation:

Rull V and Giralt S (2018) Editorial:

Palaeoecology of Easter Island: Natural and Anthropogenic Drivers of Ecological Change.

Front. Ecol. Evol. 6:105 doi: 10.3389/fevo.2018.00105 a view that became paradigmatic and was taken as a microcosmic model for the whole planet (Diamond, 2005). Further archeological studies challenged this vision and proposed an alternative genocidal hypothesis, according to which the cultural collapse was caused by the introduction of unknown epidemic diseases and slave trading after the European contact in AD 1722 (Hunt, 2007). Under this view, deforestation took place well before the cultural collapse, and the Rapanui society was resilient to forest removal, remaining as a healthy society until the European arrival (Hunt and Lipo, 2011; Stevenson et al., 2015).

Until recently, human activities were considered to be the main drivers of ecological change and the potential influence of climatic changes was explicitly dismissed (Flenley and Bahn, 2003). However, further palaeoecological studies suggested that climate changes have been more relevant than usually thought. Since the onset of the twenty-first century, lake and peat coring intensification has refined our view of the main palaeoclimatic trends since the last glaciation, and their potential relationships with landscape and ecological changes, have been investigated more intensively (Sáez et al., 2009; Rull et al., 2013; Rull, 2016). This has opened a new era in the study of Easter Island's climatic and ecological histories, which has questioned former paradigms. An update of the new findings obtained seems pertinent to summarize the state-of-the-art and to realize where future research should be focused. This is the main purpose of our Research Topic, which is also an opportunity for sharing knowledge among the different disciplines and points of view on Easter Island's palaeoecology. The Research Topic was open to all researchers and research teams working in palaeoecological issues or in other fields of research with palaeoecological implications, including present-day ecological, cultural, and climatic aspects.

The first paper (Rull et al.) introduces the topic from a multidisciplinary perspective. The recently found palaeoecological evidence of climatic change during the last millennia is placed 
in a chronological and cultural context to disentangle the role of natural and anthropogenic drivers of socio-ecological change. It is concluded that a transdisciplinary synthetic approach including every type of available evidence is needed to resolve the ecological and cultural history of Easter Island since its human settlement. In order to facilitate this task, the second paper summarizes all the chronological information obtained to date (1984-2015) using radiocarbon dating of lake and peat sediments from the three coring sites available on the island (Rano Aroi, Rano Kao, and Rano Raraku). This database, called EIRA (Easter Island Radiocarbon Ages), is useful to develop new and customized age-depth models, as well as to plan further coring campaigns.

The second part of the Research Topic consists of two papers focused on human settlement using DNA phylogenies to unravel the timing of colonization and the origin of the first settlers. West et al. base their colonization model on the human-transported Pacific rat (Rattus exulans) as a proxy for human migrations across Oceania. Using mitochondrial DNA, these authors find support for a Polynesian origin of the first settlers and propose a novel migration route. In the second paper, Thorsby reviews the available genetic evidence (human DNA) on an eventual early contribution of Amerindians to the island's culture. The author concludes that, although the first settlers could have been arrived from Polynesia by AD 1200-1253, there is firm evidence for native Americans to have reached Easter Island by AD 1280-1495.

The third section deals with human demographic trends in relation to the available natural resources. In the first paper, Merico reviews the topic with emphasis on economic and ecological aspects, and discusses the models considered to date for the cultural collapse as a result of over-exploitation. The author recommends the use of Agent-Based Models (ABM), still unexplored on Easter Island, as a useful tool to address

\section{REFERENCES}

Diamond, J. M. (2005). Collapse: How Societies Choose to Fail or Succeed. New York, NY: Viking.

Flenley, J. R., and Bahn, P. G. (2003). The Enigmas of Easter Island. Oxford: Oxford University Press.

Flenley, J. R., and King, S. M. (1984). Late quaternary pollen records from Easter Island. Nature 307, 47-50. doi: 10.1038/307047a0

Flenley, J. R., King, S. M., Jackson, J., Chew, C., Teller, J. T., and Prentice, M. E. (1991). The late quaternary vegetation and climatic history of Easter Island. J. Quat. Sci. 6, 85-115. doi: 10.1002/jqs.3390060202

Heyerdahl, T. (1989). Easter Island. The Mystery Solved. New York, NY: Random House.

Hunt, T. L. (2007). Rethinking Easter Island's ecological catastrophe. J. Archaeol. Sci. 34, 485-502. doi: 10.1016/j.jas.2006.1 0.003

Hunt, T. L., and Lipo C. P. (2006). Late colonization of Easter Island. Science 311, 1603-1606. doi: 10.1126/science.1121879

Hunt, T. L., and Lipo, C. P. (2011). The Statues that Walked. New York, NY: Free Press.

Rull, V. (2016). Natural and anthropogenic drivers of cultural change on Easter Island: review and new insights. Quat. Sci. Rev. 150, 31-41. doi: 10.1016/j.quascirev.2016.08.015

Rull. V., Cañellas-Boltà, N., Sáez. A., Margalef, O., Bao, R., Pla-Rabes, S., et al. (2013). Challenging Easter Island's collapse: the need for human-resource interactions. The second paper (Puleston et al.) models the agricultural potential of the island before the European contact on the basis of climatic and soil nutrient parameters. The authors conclude that the limiting factor is nitrogen availability and estimate that pre-European conditions would have supported population sizes of 17,500 or even higher. Lipo et al. comment on this paper and seriously question Puleston et al. demographic figures, based on purported modeling flaws. The points of Lipo et al. are answered in a second commentary by Puleston et al.

The concluding paper of this Research Topic (Rull et al.) is an attempt to merge the evidence from various disciplines -mainly palaeoeclimatology, palaeoecology, archeology, and historical records-into a holistic framework called CLAFS (ClimateLandscape-Anthropogenic Feedbacks and Synergies), to address the deforestation timing of the island and its potential causes, and the cultural shift that determined the disappearance of the moai culture. Several working hypotheses are postulated and the better suited testing methods are proposed, based on the use of new palaeoecological proxies (biomarkers) and the combination of multiple fields of research. We hope that this Research Topic will contribute to increase our understanding of Easter Island and to stimulate transdisciplinary collaboration.

\section{AUTHOR CONTRIBUTIONS}

VR wrote the paper and SG edited the manuscript and approved submission.

\section{ACKNOWLEDGMENTS}

This Research Topic is dedicated to the memory of John R. Flenley, the pioneer of paleoecological study of Easter Island, who passed away on June 22, 2018.

interdisciplinary synergies. Front. Ecol. Evol. 2:3. doi: 10.3389/fevo.2013. 00003

Sáez, A., Valero-Garcés, B., Giralt, S., Moreno, A., Bao, R., Pueyo, J. J., et al. (2009). Glacial to Holocene climate changes in the SE Pacific. the Raraku Lake sedimentary record (Easter Island, 27 S). Quat. Sci. Rev. 28, 2743-2759. doi: 10.1016/j.quascirev.2009.06.018

Stevenson, C. M., Puleston, C. O., Vitousek, P. M., Chadwick, O. A., HaoaCardinali, S., and Ladefoged, T. N. (2015). Variation in RapaNui (Easter Island) land use indicates production and population peaks prior to European contact. Proc. Natl. Acad. Sci. U.S.A. 112, 1025-1030. doi: 10.1073/pnas.14207 12112

Thorsby, E. (2012). The Polynesian gene pool: an early contribution by Amerindians to Easter Island. Philos. Trans. R. Soc. Lond. B. Biol. Sci. 367, 812-819. doi: 10.1098/rstb.2011.0319

Conflict of Interest Statement: The authors declare that the research was conducted in the absence of any commercial or financial relationships that could be construed as a potential conflict of interest.

Copyright $\odot 2018$ Rull and Giralt. This is an open-access article distributed under the terms of the Creative Commons Attribution License (CC BY). The use, distribution or reproduction in other forums is permitted, provided the original author $(s)$ and the copyright owner(s) are credited and that the original publication in this journal is cited, in accordance with accepted academic practice. No use, distribution or reproduction is permitted which does not comply with these terms. 